Meta

Journal des tradlucteurs

Translators' Journal

\title{
Culture Vulture
}

\section{Patricia D. Claxton}

Volume 12, numéro 1, mars 1967

URI : https://id.erudit.org/iderudit/002338ar

DOI : https://doi.org/10.7202/002338ar

Aller au sommaire du numéro

\section{Éditeur(s)}

Les Presses de l'Université de Montréal

\section{ISSN}

0026-0452 (imprimé)

1492-1421 (numérique)

Découvrir la revue

Citer cet article

Claxton, P. D. (1967). Culture Vulture. Meta, 12(1), 9-13.

https://doi.org/10.7202/002338ar

Ce document est protégé par la loi sur le droit d'auteur. L'utilisation des services d'Érudit (y compris la reproduction) est assujettie à sa politique d'utilisation que vous pouvez consulter en ligne.

https://apropos.erudit.org/fr/usagers/politique-dutilisation/
Cet article est diffusé et préservé par Érudit.

Érudit est un consortium interuniversitaire sans but lucratif composé de l'Université de Montréal, l'Université Laval et l'Université du Québec à Montréal. Il a pour mission la promotion et la valorisation de la recherche. https://www.erudit.org/fr/ 


\section{culture vulture}

My tardiness at our rendezvous was a disaster:

from that moment on my life has been fractured.

This is the opening sentence of a translated excerpt from Prochain épisode by Hubert Aquin, one of several which appeared in a recent issue of Maclean's Magazine ${ }^{1}$. Take the sentence above and calque it back into French, word for word in that order, and you have the original. The rest goes to match, and the total effect is ludicrous. The French syntax is followed throughout, with French punctuation, and where the straight literality or calque yields something that is just too, too garbled for words, the translator cooks up something else which is pure invention in varying degrees of inaccuracy (or leaves it out altogether - $O$ happy solution !). Take the following, for example: J'agonise sans style, comme mes frères anciens de Saint-Eustache ${ }^{2}$, which becomes: The agony has no outlet, just as it had none for my comrades that time in Saint-Eustache. On top of everything else, the translator has completely missed an obvious allusion here to the Revolt of 1837.

My initial reaction was one of amusement, but my amusement soon turned to dismay as I realized that this travesty, this utter nonsense, was being presented as serious literary translation. The last straw, when I turned to the original text, was to find that the translator had obviously embarked upon translating the excerpts without first reading the book. There are certain sustained images of quite lyrical beauty, and allusions to other parts of the book, which are completely lost, and where the images have an erotic content it is the erotica alone which comes through, and that is purely grotesque.

One swallow doesn't make a summer, you may say, or one falling leaf a winter, and I will readily admit that $I$ have not made an exhaustive study of the state of literary translation in Canada. But $I$ have seen enough that is bad and read and heard enough exasperated comment to be convinced that we could and should do much better.

In a recent column headed «English Viewers Probably Slept 》, the Montreal Star's radio and television critic, Pat Pearce, wrote: « The CBC's English network viewers are likely to have a pretty funny idea of what goes on on the French network if they judge by the hour-and-a-half they saw last night. 》 She was referring to two

1. «The Next Episode», translation by Penny Gail Williams, Maclean's Magazine, June 4, 1966, p. 16-17, 26.

2. Hubert Aquin, Prochain épisode, Montréal, le Cercle du Livre de France, 1965, p. 139. 
programs, one a play and the other « an impressionist TV-biography ». With regard to the first, she mentions the ineffectiveness of «the artificial-sounding translation 》, and of the second she says « the long narration suffered horribly in translation. Both shows, she continues, and particularly the translations, were self-conscious. They were literal, not idiomatic. They emphasized not at all inner people, but a kind of $\ll z o o »$ element of the strangers in our midst. $\gg^{3} I$ watched the second of these programs, and I soon found myself taking notes on certain incongruities. Here are some examples:

I was homesick almost to the point of madness; very strong, this; an AngloSaxon takes madness pretty literally, but doesn't mind saying, for instance, that he was almost out of his mind.

I want people around here to breathe freely; all together, now, up on your toes; in - one, two, three; out - one, two ...

$I$ had been mixed up in a big adventure; this is a grown man speaking of Quebec's social revolution, not a child talking about haunted houses and buried treasure.

I prefer things to ideas;....

It is not enough to be able to read intelligently in order to translate. Details in writing, for instance, should form such an integral part of the whole that they contribute to the whole without drawing particular attention to themselves. For the reader, a detail which is not entirely clear can be passed over almost unnoticed, but when it is translated such an obscurity may well present so grotesque an aspect that it becomes far more important than it was ever intended to be. What better example of this than the well-known boner by the translator of Gabrielle Roy's Bonheur d'occasion (The Tin Flute), who invented an explosion in a powder factory in rendering la poudrerie éclata, when all the author had in mind was a snow flurry ${ }^{4}$. I need hardly point out that regional colloquialisms are not the only source of confusion. Writers who tax the semantic and grammatical limits of their own language are particularly difficult to translate with any measure of coherence. Here is where translation borders on the impossible, but assuming the piece is worth translating, here, too, is the translator's consummate testing-ground.

The notion of artistic integrity in translation is by no means new. In 1791, Alexander Fraser Tytler wrote:

I would therefore describe a good translation to be, that, in which the merit of the work is so completely transfused into another language, as to be as distinctly apprehended, and as strongly felt, by a native of the country to which that language belongs, as it is by those who speak the language of the original work ${ }^{5}$.

A good translator must be able to discover at once the true character of his author's style. He must ascertain with precision to what class it belongs; whether to that of the grave, the elevated, the easy, the lively, the florid and ornamented, or the simple and unaffected; and with these characteristic qualities he must have the capacity of rendering equally conspicuous in the translation as in the original. If a translator fails in this discernment, and wants this

3. The Montreal Star, July 21, 1966, p. 16.

4. Harry Lorin Binsse, «An Intellectual Iron Curtain?», The Montreal Star, Sept. 22, 1962, Entertainments Section, p. 2.

5. Alexander Fraser Tytler, Lord Woodhouselee, Essay on the Principles of Translation, Everyman Edition, 1791, p. 8-9. Quoted by L. Bonnerot, Chemins de la traduction, Paris, Didier, 1963, p. 17. 
capacity, let him be ever so thoroughly master of the sense of his author, he will present him through a distorting medium, or exhibit him often in a garb that is unsuitable to his character ${ }^{6}$.

A hundred and forty years later, Hilaire Belloc was saying the same thing:

... we should say to ourselves, not « How shall I make this foreigner talk English ? » but «What would an Englishman have said to express the same ? 》 That is translation. That is the very essence of the art: the resurrection of an alien thing in a native body; not the dressing up of it in native clothes, but the giving to it of native flesh and blood 7 .

Channel:

Then and later the same thing was being said in a different way across the

C'est une création artistique au sens de l'acteur créant ou recréant un rôle ${ }^{8}$.

En dehors de son sens matériel et littéral, tout morceau de littérature a, comme tout morceau de musique, un sens moins apparent, et qui seul crée en nous l'impression voulue par le poète. Eh bien, c'est ce sens-là qu'il s'agit de rendre, et c'est en cela surtout que consiste la tâche du traducteur. S'il n'en est pas capable, qu'il se contente d'être un lecteur; ou bien, s'il tient absolument à traduire, qu'il s'attaque à n'importe quelle matière imprimée ou manuscrite: ouvrages de philosophie et d'histoire pures, traités scientifiques, manuels, et au besoin documents légaux ou commerciaux, mais qu'il laisse Virgile, et tout ce qui est littérature, tranquille; mais pour rendre ce sens littéraire des ouvrages de littérature, il faut d'abord le saisir; et il ne suffit pas de le saisir: il faut encore le recréer ${ }^{9}$. more:

And in the eighteenth century and the twentieth too, some would say even

L'auteur qui compose, conduit seulement par une sorte d'instinct toujours libre, et par sa matière qui lui présente des idées qu'il peut accepter ou rejeter à son gré, est maître absolu de ses pensées et de ses expressions : si la pensée ne lui convient pas, ou si l'expression ne convient pas à la pensée, il peut rejeter l'une ou l'autre; qua desparat tractata nitescere posse, relinquit. Le traducteur n'est maître de rien; il est obligé de suivre partout son auteur, et de se plier à toutes ses variations avec une souplesse infinie ${ }^{10}$.

... il fait une manière de chef-d'œuvre en produisant des poèmes dont la substance n'est pas de lui, et dont chaque mot est prescrit par un texte donné. Je me retiens à peine de prétendre que le mérite de venir si heureusement à bout d'une telle tâche est plus grand (et il est plus rare) que celui d'un auteur complètement libre de tous ses moyens ${ }^{11}$.

In Canada, as we all know, translation has been fighting an uphill battle. A few years ago, Harry Lorin Binsse, to my knowledge the most distinguished of Canadian

6. Alexander Fraser Tytler, Essay on the Principles of Translation, p. 63-64. Quoted by L. Bonnerot, Chemins de la traduction, p. 133.

7. Hilaire Belloc, On Translation. The Taylorian Lecture, 1931, p. 34. Quoted by L. Bonnerot, ibid., p. 69.

8. Abel Chevalley, «Enquête sur la traduction 》, Cahiers du Sud, nº 89, avril 1927, p. 263. Quoted by L. Bonnerot, ibid., p. 172.

9. Valery Larbaud, Sous linvocation de saint Jérôme, Paris, Gallimard, 1946, p. 69-70. Quoted by L. Bonnerot, ibid., p. 213.

10. Charles Batteux, De la construction oratoire, quoted by A. F. Tytler, op. cit., p. 112-113. Quoted by L. Bonnerot, ibid., p. 137.

11. Paul Valéry, Préface à les Cantiques spirituels de saint Jean de la Croix, traduits en vers françois par le R.P. Cyprien, carme déchaussé, Ed. Art catholique, 1941. Quoted by L. Bonnerot, ibid., p. 270. 
French-English translators, wrote an article explaining the difficulties of publishing translations in Canada, summarizing both French and English-Canadian literature available in translation, and calling for « a wholly systematic and inclusive program $\gg$ of grants by the Canada Council to alleviate the economic difficulties besetting the publication of translations" 12 . The Canada Council has in fact by now made a number of such grants, but in too many cases, $I$ fear me, it is mediocrity which is being subsidized, and if that state of affairs continues it will do more harm than good. A glance over the fence on the part of either of our two cultures is not likely to be habit-forming unless it pleases. Quite the contrary. Since Council grants are made to publishers, not to translators, it must be that either there is a shortage of really competent literary translators, or the publishers do not know the difference between good and bad translation. I would hate to think that they do not care. Whatever the reason, the translating profession has cause for alarm.

Mr. Binsse believes, with Edmond Cary and Gide, that a literary translator is a writer first, and with this I have no quarrel. Says Cary: « La traduction litteraire n'est pas une opération linguistique, c'est une opération littéraire. $\rangle^{13}$ However, highly competent writers often fall flat on their faces when they attempt to translate. Why? Not because of shortcomings in their grasp of the resources of their own language, but because they do not understand the comparative functions of both their languages in all their complexities and subtleties, nor the delicate relationships between the functions of one and the functions of the other. These are the linguistic aspects, and these may be acquired through formal study as a systematic discipline, a science, by anyone possessing a certain intelligence and the desire to learn; the artistic aspect is a gift that may be developed but not created. The translator possessing natural gifts of both is a very rare bird.

My disagreement with Mr. Binsse is with his comfortable belief that, given the right economic and cultural background, competent translators will « appear ». They may indeed, but in this jet age when things move too fast to allow evolution to take care of everything in its own good time, I don't think we can wait that long. The science of linguistics is ready and available here and now to bridge the gap for the translator with a writer's artistic sensitivity for language; the techniques of comparative stylistics developed by Messrs Vinay and Darbelnet are specifically designed for that purpose ${ }^{14}$.

With the need for translators in technical and specialized fields growing incessantly, the emphasis in training understandably falls upon non-literary aspects of translation. Even in translating circles, literature and all things cultural tend to be regarded as something of a luxury. Literary translation courses as I know them serve primarily as base and background for other specialized work, or as an exercise in linguistics, and are directed at students who are not necessarily interested in pursuing the subject as an end in itself. And yet it is in literary translation above all where the special skills and knowledge necessary to a high level of competence cannot be learned on the job. I would like to see the institution of a program of advanced

12. Harry Lorin Binsse, loc. cit., p. 2 .

13. Quoted by Georges Mounin, les Problèmes théoriques de la traduction, Paris, Gallimard, 1965, p. 13.

14. J.-P. Vinay et J. Darbelnet, Stylistique comparée du français et de l'anglais, Paris, Didier, et Montréal, Beauchemin, 1958, $331 \mathrm{p}$. 
formal study intended specifically to prepare literary translators, and restricted to a small number of students selected for aptitude and serious intent from preliminary courses.

Such a program might, for instance, fit into the framework of the Maîtrise en traduction at the University of Montreal, with a special mention, perhaps, or might be the object of an additional certificate following the Maitrise. It might be open to partial students, but only on successful completion of certain prerequisite courses, particularly the courses of Stylistique comparée. It should include study of semantics and period style in both languages, versification, dramatic technique, and techniques of radio and television scripting. Most important of all, it should include a seminartype course undertaking the translation of the most difficult texts, the practical application, on the highest level, of Stylistique comparée. Texts would be assigned well ahead, and each week a translation would be distributed, with its original text, for study and subsequent discussion the following week, the final corrected version being the product of class consensus. A healthy percentage of the final mark should be assigned for the constructiveness of each student's participation throughout the year; this to assure a commensurately healthy level of discussion. However, where the texts are sufficiently difficult, and the students genuinely interested, there should be no trouble in achieving a lively participation. Depending on the number of students, each would prepare, say, one thème and two versions in the course of the year. Ideally, the class would be evenly divided between students of each mothertongue, but no doubt such a situation would be difficult to arrange. Such a seminar would be very demanding upon its leader, of course, and the task might be shared between two leaders, one of each mother-tongue, alternating according to the target language under discussion.

This is aiming high, but that is the intention. It takes account of the fact that literary translation is highly personal, the seminar providing what seems to me an ideal multiple sounding-board for the budding translator. Each student might even be encouraged to introduce a difficult text of his own choosing, subject to approval, of course. By the completion of the program each should enjoy the confidence of having seen and grappled with problems as difficult as any he is likely to encounter, under the critical eye and with the constructive comment of others whose interest and intent are as serious as his own. And yet in the process he should acquire a clear recognition that there are no pat answers, and that every new problem is a new challenge.

Apart from such a training program, I have two other proposals for encouraging an improvement in literary translation. First would be an annual prize for excellence, carrying at least a token cash award, but above all intended to carry great prestige; a Governor-General's Prize, or an equivalent. It should not be awarded at all in years where no translation of really great merit is accomplished. Second, a vigilant committee set up by the profession to survey as many literary translations as possible (including radio and television scripts). This committee would make recommendations for the above prize, but as its principal function it would award stars in ascending multiples for good translations and some other appropriate symbol for bad ones; skulls and cross-bones, I suggest.

Patricia D. Claxton 